\title{
ILLEGAL FINANCIAL SERVICE BUSINESS AND ACCOUNTING PRACTICE IN PASAR BESAR MALANG
}

\author{
Fitriana Rakhma Dhanias ${ }^{1}$, Unti Ludigdo ${ }^{2}$, Aji Dedi Mulawarman ${ }^{3}$ \\ ${ }^{1}$ Postgraduate Program Faculty of Economic and Business, University of Brawijaya, \\ Malang-Indonesia.Email: fitrianarakhma1705@gmail.com \\ ${ }^{2,3}$ Faculty of Economic and Business, University of Brawijaya, Malang-Indonesia
}

\begin{abstract}
Originated from the rapid flow of commerce accompanying the economic development ranging from macro to micro sectors, impacts on the large amount of available capital options. This phenomenon indicates that not only financial services such as banking, Public Loan Bank (Bank Perkreditan Rakyat), and cooperation exist, but also illegal financial services, which enliven capital activities amongst traditional market merchants. This research aims to explore the existence of accounting in illegal financial service business in Pasar Besar Malang. The researchers use ethnomethodology as the research method as it has more points in understanding empirically. Ethnomethodology is an empirical study which learns how humans catch and carry out their daily activities within a social reality. The result of this research finds that accounting does exist in illegal financial service business in Pasar Besar Malang where the presence of accounting in loansharks business practice is also influenced by local values of Javanese culture.

Keywords: loansharks, ethnomethodology, accounting
\end{abstract}

\section{INTRODUCTION}

Loansharks accounting, is a phrase which make most people frown. This accounting is still unfamiliar for most people. Research on loansharks accounting might not be available in Indonesia yet. Though, it is widely known that accounting is a study which affects the success of a business (Boyle and Desai, 1991; Palmer and Palmer, 1996, also Mbogo, 2011). It is not impossible that accounting exists in loansharks business. Until today, scientific accounting research in Indonesia is still focused on corporate accounting, which is conglomerate business with large amount of capital; particularly the company that goes public. Nevertheless, non-corporate business, which commonly referred to as micro business in Indonesia,is actually growing rapidly. Specifically in the retail sector in traditional market, the Ministry of Industrial and Commerce Affairs stated that there were 13,450 traditional markets in Indonesia with 12,6 millions merchants serving the daily needs of nearly $60 \%$ of the population in 
Indonesia (Firmansyah and Halim, 2013:113). It is inevitable that scientific accounting research in the domain of non-corporate business is greatly worth to be explored. Thus, the researchers are trying to uncover the reality of accounting from the other side, which is moneylenders accounting, making this research in the domain of non-corporate accunting.

\section{Accounting as Shade in Life's Dynamics}

The presence of accounting has quite big influence in life's dynamics and fill every alcove of economic events. Not only in the scope of capital market and large corporations, accounting as a branch of social science, is able to give essence to every phenomenon. Accounting practice cannot be separated from the culture in which the accounting is practiced (Ahrens and Mallona, 2004)

The form of accounting practice has certain definition to each person, it depends on the culture followed by the person. The thought brings out a wide range of works that seek to provide a subjective understanding towards various phenomena in the area of accounting. Accounting as a field of value-loaded science, is obviously able to be used as a perspective to explore of loan sharks practice as an option of capital source are still being the favourite of the merchants in traditional market and managed by the values of local wisdom of local community.

\section{Interactions between Accounting and Illegal Financial Service}

Accounting as a field of value-loaded science, is obviously able to be used as a perspective to explore of loan sharks practice as an option of capital source are still being the favourite of the merchants in traditional market and managed by the values of local wisdom of local community. Related to the issue of accounting and loan sharks, Soudijn and Zhang (2012) researched the relations between accounting and Chinese loan sharks practice in a Casino in the Netherlands. The research resulted in a detailed analysis regarding accounting record, which showed that Chinese loansharks worked with many clients, not only Chinese citizens, but also other non-Chinese citizens. High interest charged on loans and the lent money figures showed the loansharks performing activity were quite good. The records revealed a closed-environment business transactions. Some clients were from connecting social network and from word of mouth.

Further examined, it indicates that the loansharks had accounting records to assist them in running their illegal business. The records also served as a financial statement such as transaction details or how much capital they had lent to their clients. The produced records made the loansharks believed it would be very helpful in running their business. These findings are consistent with the statement of Megginson et al 
(2000) that accounting has an important role to achieve the success of a business, including for small or micro business performers. Loansharks was apparently also used accounting to support their business. This study proved Chinese loansharks rapid growing business judging from their accounting records.

Melzer and Schroeder (2015) also researched accounting practice of illegal financial service focusing on loan approval by loansharks by taking a case study on automobilecredit. The research studied the practice of loansharks restriction effect in the market for automobile credit, by finding the evidence that usury restriction cause the decreasing credit ratio. This research also analyzed accounting practice for credit risk by adjusting sales price and loan amount compared to using interest rate. The automobile dealer arranged a loan with the same amount of monthly installment and balanced the credit risk by marking up the product sales rather than using credit interest rate.

The transformation of capital or debt provision by loansharks has become a quantitave interaction in a business activity and the existence of a systematic accounting, from its recording, calculation of credit interest, social accountability, to its decisionmaker implicates the interaction between accounting and illegal financial service. At last, the collaboration of accounting and illegal financial service practice creates a reality in the dynamics of social economy.

\section{Illegal Financial Service amongst Traditional Market Merchants: Love-and-Hate Symbiosis}

Capital source of illegal financial service is the easiest 'shortcut' to satisfy the needs, especially for traditional market merchants, though they realize that the consequences of loansharks practice are there for them to face later on. A phrase which can describe this situation is a "love-and-hate" symbiosis. The existence of loasharks is still considered unusual for most people but is needed for some segment of the society, especially traditional market merchants. In Indonesia, research on illegal financial service has not been done yet. Therefore, illegal financial service accounting will be an interesting issue to be analyzed for the development of accounting study.

Several researches has analyzed the case of loansharks, but none has addressed in terms of accounting. As a research done by Permana (2010) which examined the practice of loansharks as an aggressive underground economy since the local community support the system. The reason was people felt that they were difficult to gain access to loans from banks and other formal financial insitutions because of the conditions that binded the loans.

Saputra (2012) researched from the economical institution aspect regarding bank thithil (a-little-at-a-time bank) practice in Bethek slum area in Malang. The study found that the local community depended on bank thithil creditor offers because of their minimum income compared to their spendings as well as the difficulty to access formal financial service to get loans for their daily needs and venture capital. 
Kartono (2004) observed loansharks from a sociological point of view. Illegal financial service or loansharks was called traditional capital market. The study found that loansharks was a form of traditional capital market born as a social phenomenon. The structural element and social relationships produced its characteristics and dynamics. The aspects of trust and daily interaction became part of the traditional capital market operation mechanism, either to attract customers, suppress the competiton, and monitor the obedience. Consumption market (pasar Masaran) where the capital market was observed also revealed similar social symptoms. It seemed that the market structure and dynamics were related to the structure of traditional capital market developed there.

Observed from the economical aspect, traditional market is the go-to spot for loansharks because the economic transactions are dynamic with such great numbers of merchant. Local values of adhered traditional market merchant also allows the system of illegal financial service to run. The existence of accounting is an influential factor of public accounting construction. Some early accounting researchers, such as Hofstede (1987), Gray (1988), Perera (1989), Belkaoui and Picur (1991)assumed that accounting is a socially constructed reality that accounting practice cannot be separated from its surrounding cultural context.

As a basis in finding the existence of accounting in illegal financial service practice in Pasar Besar Malang, this research uses accounting as a socially constructed reality which resulted from interactions within a social order. As a socially constructed reality, the person in a society can construct accounting based on their beliefs, values, and social norms. Also, illegal financial service, which has different cultural values from formal financial service, has a different kind of accounting. Based on previous research, as none has raised the topic of loansharks from accounting perspective, the researchers are inspired to reveal it. As a step to look at the meaning behind the described phenomenon, the researchers are encouraged to uncover the practice of business and accounting in illegal financial service amongst traditional market merchants. The findings from the exploration of the accounting existence, which based on local values in illegal financial service activities, theoretically can initiate new perspective in the development of accounting generally from the perspective of social and cultural theory.

\section{RESEARCH METHODOLOGY}

\section{Interpretive Paradigm}

This research is aimed to find the existence of accounting in business practice of illegal financial service amongst traditional market merchants of Pasar Besar Malang. The researchers then decides to use interpretive paradigm. The objective of this paradigm is to analyze the social reality and how the social reality is formed (Chariri, 2009). The conducted accounting research using interpretive paradigm seeks to uncover 
the hidden meaning behind a symbol. After finding the hidden meaning, the researchers then comprehend the meaning of the accounting symbol (Burrel and Morgan 1979; Chua 1986).

Interpretive paradigm is considered able to accomodate this research. Comprehension on the existence of accounting in illegal financial service practice amongst traditional market merchants in Pasar Besar Malang can be achieved. From the doer experience, the accounting practice form, to the social order occurs within illegal financial service activity interaction. In accordance to the statement of Ludigdo (2007: 68 ) regarding interpretive paradigm, which explain that a comprehension of fundamental nature of social world at the level of subjective experience, comprehension which points at the existence of social order, consensus, integration and social cohesion, solidarity, and actuality.

\section{Qualitative Research}

This research can categorized as a qualitative research. As stated by Denzin and Lincoln (2009), qualitative research is a research performed in certain setting in a real life (natural) to investigate and comprehend a phenomenon: what happen, why it happen, and how it happen. Qualitative research is based on the concept of "going exploring" involving in-depth and case-oriented study over a number of cases or a single case. Another definition is described by Creswell (2009: 4) that qualitative research implies the effort of extracting and understanding the meaning of what is happening in several individuals or groups who has social problems or humanity problems.

\section{Ethnomethodolody: A method of Digging the Existence of Accounting in Illegal Financial Service in Pasar Besar Malang}

Accounting practice is closely related to social reality. To be focused on the subjective experience on a person and the way he face his world, the researchers are required to use the appropriate method therefore the meaning of the object can be deeply explored (Mason, 1996). In short, the emphasis of ethnomethodology is how or by what method, a person comprehend his daily world (Atkinson, 1988; Bosrowi and Sudikin, 2002:53; Poloma, 2007: 282 and Denzin and Lincoln, 2009: 338). Based on the explanation above, this research uses ethnomethodology as an approach to the social reality occurs in illegal financial service activity in traditional market merchants of Pasar Besar Malang.

The researchers decides to use ethnomethodology in this research because it focuses on how the presence of accounting created between daily interactions of the illegal financial service agents with the traditional market merchants in Pasar Besar Malang. Accounting practices emerged is the essence created from the experience of daily life of the interactions between the loansharks with their clients and is believed mutually and colors local values in the scope of Pasar Besar Malang. 


\section{Data Source}

This research uses two kinds of data sources: primary and secondary data. Primary data are obtained from interviews with the agent of illegal fincancial service in traditional market merchants of Pasar Besar Malang. The secondary data are obtained from literature and articles on illegal fiancial service, loansharks, micro-enterprises accounting, and other literatures supporting this research.

\section{Research Location}

This research is conducted in a traditional market, called Pasar Besar Malang. The market is the largest traditional market in Malang, the huge number of merchants makes the complexity of the interaction existing among merchants, buyers, and capital service providers are very diversed. Secondly, the access to the site is easy. Third, the illegal financial service agents have the highest clients in the market. Fourth, the researchers are close with the illegal financial service agents who become the key informant aiding the researchers to obtain data.

\section{Research Informant}

Subject or object of a research is a source of information on the instruments to be processed in the research (Zulganef, 2008). The subjects are key informants and supporting informant. Key informants in this reasearch are loansharks, and supporting informants are the market merchants. Informants are selected through some criteria to be elligible as informants. The names of informants are not their real name. For information, Mrs. Saritem and Mr. Nasution are loansharks operating in Pasar Besar Malang. Mrs. Saritem mother has started the business since 1958, while Mr. Nasution carries on the business from his father since 1990. Mr. Nasution is the second generation of his family to run the loanshark business. The loansharks have known each other and run the business in good manner. The researchers also points Mrs. Tarmini and Mr. Kipli as informants who serve as the debtor of loansharks in Pasar Besar Malang aiming for verification. The researchers wants the merchants to verify the obtained data to be more accurate.

\section{Data Collecting Technique}

In a qualitative research, there are some data collecting techniques, such as observation (participative or non-participative), interview (semi-structured to unstructured) and documentation (Creswell, 1998: 121). The researchers use participaive observation by blending directly in the activities. Collecting data method used is indepth interview approach. In this reasearch, research document are records relating to business practice and the accounting of illegal financial service in Pasar Besar Malang. 


\section{Data Analysis Technique}

As mentioned, this research uses ethnomethodology approach. Coulon (2008) mentioned that there are several ways used by researchers to analyze ethnomethodology data, which are stages of indexicality, accountability, and reflexivity. Indexicality, accountability, and reflexivity are important concepts in ethnomethodology (Basrowi and Sudikin, 2002; Muhadjir, 2000: 145; Coulon, 2008: 38-53 and Denzin and Lincoln, 2009: 339). The analysis processes start from the initial stage to the stage of conclusion of research results. The analysis processes include the following steps: a) data reduction, b) data presentation, c) Domain analysis consisting indexicality, accountability and reflexivity, and d) conclusion.

\section{RESEARCH AND DISCUSSION}

\section{Hacking Loansharks Business Traces in Pasar Besar Malang: The Go-To Spot for Loansharks}

Pasar Besar Malang is the largest market in Malang. Almost all daily needs of clothing and food are sold there. Pasar Besar Malang is a "one-stop-shopping" for traditional market segment. Though hectic, Pasar Besar Malang still shows harmonious social life. Interactions among merchants results in social patterns such as mutual support and help among traditional market merchants in Pasar Besar Malang. The majority of the Market community is Javanese people, whosel livelihood is commerce. This affect cultural values of Local Javanese values that come into practice of loansharks, which also influence and color the accounting practice of the loansharks. There are several capital providers available for traditional merchants. Ranging from banking, cooperation, Public Loan Bank, to BMT. Yet, these formal institutions become the last choice for the merchants because of their complicated procedural issues. Loansharks is an ultimate preference for capital provider to the merchants of Pasar Besar Malang.

Loansharks activities enrich the life of market merchants similar to a symbiosis, a Love-and-Hate symbiosis. Feeling hate due tothe paid interest is above bank interest rate, yet love due to its flexibility, fast process, easy access, no collateral, no penalties, even it rewards cutting the credit period. These make the statement that loansharks activities in running their business cannot be separated from the growing value system exists in the society. This makes loansharks more exist in Pasar Besar Malang.

Every business must be exposed to risks. There is no exception to loansharks business in Pasar Besar Malang as well. Non Performing Loan (NPL) risk is oftenly faced by loansharks as the agent of illegal financial service. Credit disbursement frequently does not return on time as prearranged period. Loansharks in Pasar Besar Malang are more flexible facing the risks of bad debt. They consider consider the risk of 
delayed installments or even bad credit as a form of charity. There are no significant efforts taken by the loansharks facing this bad credit.

Loansharks in Pasar Besar Malangare consent (rila) and accept (nrima)in running their business and dealing with debtors. Sutoyo (1990) explained that in Javanese culture, the intention of helping each other is the representation of consenting (rila) and accepting (nrima) creating balance to form new value, and to open opportunities to act structurely. It is proven that consent and accept as the main elements of Javenese culture are closely related to the activity of loansharks in Pasar Besar Malang. Consent (rila), or sincere, is a willingness of giving the whole property, ability, and works to God. Accept means remain grateful for everything received and concede the destiny in God's hand without rebelling.

\section{Loansharks Diary: Understanding Illegal Financial Service Accounting Practice}

Accounting is very closely related to numbers. Yet, accounting does not only aligning figures. If explored, accounting has deeper meaning. Accounting practice cannot be separated from the culture in which the accounting is performed (Ahrens and Mollona, 2004; Suko Harsono, 2009). The presence of accounting has its own definition for each of its agent, depending on the culture adopted by the agent. Accounting practiced by the illegal financial service as micro finance business agent might be different as loansharks in other places.

In the world dominated by capitalism, accounting information is often perceived as series of numbers describing every account in a financial statement. The larger the number, the greater profit it is. This statement is not entirely wong, however, things that should be understood is that behind the numbers there is a value needed to be interpreted. Values arising from the accounting practice, such as control, morality and transpararency are worth exploring. Accounting numbers will support based on its background value. Those values are the core of accounting practice.

\section{Ngutang (debting): Going concern consideration, skeptism, and being accurate (titis) to lend money}

Agents of illegal financial service in Pasar Besar Malang also consider to decide their capital business. Accuracy in deciding the capital would be very useful for loansharks. Being sharp to prospective debtor will avoid risk of defaults and debt delay. This is the statement of Mrs. Saritem regarding consideration in providing capital:

(in Javanese) "Yo ndelok awal. Tak takoni dodolan opo, kerjo opo.Ndelok rupone pisan. Lek wes ngono kari mbalik nang atiku." 
"I look it earlier. I will ask his goods, works. I will also look at his appearance. Then, i leave it to my heart." (while patting her chest)

The implied meaning of the consideration in deciding on the provision of capital from the loansharks is to look at the business. It is seen here that loansharks consider aspects of going concern. Going concern according to Belkaoui (1997: 135) is a proposition stating the businessentity will continue to run its operations in a period of time long enough to accomplish the project, the running responsibilities as well as its activities. Besides, there is also a uniqueness of the business practices done byloansharks in considering lending decisions. Information relating to the character of the customers is not traced from track records of other financial institutions, but rather by relying on intuition regarding faces, characters, and the gesture of the prospective customer. Intuition used is a form of skepticism.

From these findings, associating with Javanese culture, it appears that the value of Javanese culture that characterizes the accounting practices are closely related to aspects of going concern and skepticism attitude is the attitude of being accurate (titis in Javanese). Titis means meticulous, observant and careful. Accuracy is in fact crucial in every activity. Loansharks who is meticulous, observant and careful in deciding the capital, must be thinking about aspects of going concern and act skeptical towards the debtor.

\section{"Notes" and "The Big Book": Accounting Products Record Loansharks}

The domination of capitalism brings out to the implication that the accounting are always associated with the presence of balanced records of debit and credit. Thus, if the application of financial records does not usethe process of "debit-credit" then it can be considered that that is not an accounting domain. The assumption cannot be justified and cannot be blamed anyway. However, eluding accounting practices where the process is not through the mechanism of debit and credit is an unwise decision. Accounting applied by one group can be different from the accounting is applied in other groups. Differences in the application of accounting emerge from the existing value in the community in which the accounting is practiced. Accounting is a field that is loaded with values, which are fused in which accounting is applied (Morgan, 1988; Francis, 1990; Triyuwono, 2012). Accounting cannot be removed from its environment as an organism that cannot be separated from their habitat. In the context of this study, accounting practice affects or is affected by the behavior of individuals in the transactions of illegal financial services in the Pasar Besar Malang. Loansharks accounting records show the existence of accounting poured into the forms of accounting practices by writing occurred transactions of illegal financial services into 
therecord books. The products of sharkloans accounting records are notes and 'big book' (ledgers). This is coherent with the statement of Mr. Kipli:

(In Javanese) "Saben wong utang diwenehi notes nduk karo Ummi, Mas Darmin yo ngewenehi"

"Everyone indebted is given notes by Ummi (Mrs. Saritem), Mas Darmin also gave" (pointing to the notepad)

Mrs. Saritem also gave similar response:

(In Javanese) "Kabeh tak ke'i notes, yowes engkok aku kan eroh...Aku dewe yo nggowo catetan buku besar gawe cekelanku."

"I gave everyone their own notes, I'll know from that.. I also bring my big book for my own record"

The contained reflectivity of the records acts as a control over illegal financial services transactions with traditional market merchants inPasar Besar Malangas the debtor. Social realities that exist in the illegal financial services transactions in the Pasar Besar Malang may indicatethat the loansharkshaveapplied accounting although it is done in small scope. The research review of Boyle and Desai (1991), Palmer and Palmer (1996), as well as Mbogo (which shows accounting practices in micro business is always associated with 1) business financial management, 2) number, 3) calculation, and 4) report. Concerning this matter, accounting has already practiced, but in another form by the loansharks and traditional market merchantsalthoughthe accounting records is very simple such as notes and "big book" (ledger).

Accounting practices conducted by loansharks in the Malang Cantral Market reveals that the activities carried out solely to meet the needs of internal information limited to the interests of the debtor, which is actually a traditional market merchants in Pasar Besar Malang and the rest is the interest of loansharks as an illegal financial services actor as the capital owner and distributor. It is suggested here that the practice of accounting is in accordance with the needs and capabilities of the agents. The records made by loansharks is very simple. It is due totheir capitalist accounting knowledge background is still limited. Therefore, the recording products are limited forms of control by both sides. Namely, traditional market merchants in Pasar Besar Malang as the debtor and loansharks as the creditor. 
The notebook or so-called notes by loansharks is a small notebook. On the front cover of the book is written the name of the debtor and lists of loan installments. On every page at the top of itis written the loanprincipal amount, the loan period and the date of the loan. On each line of the book is written the date and amount of installment per day. When loansharks provide capital funds to borrowers, firstlyloansharks write the loan principal amount, the term that has been agreed for example, 30 days, 60 days or 100 days, and thedate. On the next day,loansharks start collecting thefirst installment. Moneylenders collectthe debt repayments by visiting each debtor in the Pasar Besar Malang at their kiosk. The second record product from the loansharks is a notebook they holdcalled the "big book". Big book is a notebook held by moneylenders. It contains a record of the entire debt of the debtor. Overall installment is recorded in the big book. On the page of the big book is written the name of the debtor, the principal loan amount, loan date, installment date, and installment number.

Accounting recordingproducts made by loansharks in the Pasar Besar Malangis very simple. The simplicity of the product form accounting records indirectly acknowledgetheir abilities to manage operations without complicated records. The main value of the loansharks accounting practicebackground is not so different from the opinion of Tricker (1978: 8) in Triyuwono (2012: 112) that ideology, culture, and morality of a society greatly affect the accounting practices in the community.

Loansharks business as a micro informal financial business tend to be managed privately. Since the capital is privately owned, the business does not need compilacated records. It is based on the assumption of information adequacy, which the loansharks has it all and the assumption of record interest. Loansharks' direct involvement in their business activities makes massive profits fulfillment does not need to be recorded. The existence of notes and "big book" onlypresents report on the amount of principal debt of the debtor, and the information that the debtor has deposited its debt on that day. It is considered enough for loansharks as control objectives and accountability so there is transparency in their business process. In other words, accounting was formed through the neighborhood where the accounting is practiced in a social reality. Through the simplicity of form accounting records, it is easier for debtorsand loansharks in running transaction thus attracting the interest of debtors to ask for capital and deposit payments to loansharks in Pasar Besar Malang.

\section{Interest Imposition Motive: Thirty - Ten, Sixty - Twenty, A Hundred - Thirty Five}

Interest cannot be separated from loansharks, even the trademark that is charged by loansharks are much higher than interest charged by formal financial institutions in general. Accounting Studies perspective stated that interest from demand aspect is cost of loans, and from offer aspect is income over credit purchase (Siamat, 1995: 456).

At first, interest is a thing that is not allowed, nowadays in the society's life it has transformed into something needed in people's economic activities. They think that 
interest in society economic activity is a fairness existing, because currently there is no activity that does not include interest (Nafik, 2009: 90). It is similar to theinterestimposition byloansharksinPasar Besar Malang. The amount ofchargedinterest is no longerconsidered a "bane" for the marketmerchantsas a debtor. They assumethat theinterest chargedisacompensation forthe lent capital.Seeing the advantageto borrowfrom loansharksbringsbenefitsgreaterthan thepaid cost, the interest is notconsideredamajorissueforthe debtor.This is the statement ofMr. Darminregarding this matter:

(In Javanese) "Kulo nggih sami kaliyan Bu Saritem niku, yen tigang doso dinten nggih sedoso, suwidak nggih rong puluh, satus nggih telu limo. Misale wonten tengah-tengah rugi mboten saged mbayar nggih sing penting pokok e mawon. Cicilen sak isone, kulo catet sak isone rumiyin.Yok nopo malih."

"I'm similar to Mrs. Saritem, thirty days is ten, sixty is twenty, a hundred is thirty-five. Let's say there's loss halfway not able to pay installment, pay his best. Just pay your best and i'll record it. What can I do (deep sigh)."

As withother microorganizations, loansharks accountingis intendedastheirresponsibilityas a manager, butin its management,loansharks accountingis based onthe cultural backgroundin Pasar Besar Malangthusaccountingpracticealso hasenvironment valuesin whichit is located.Seeing themajorityin Pasar Besar MalangisJavanese culture, it implies thatthe loansharksaccountingconductedin this studycolorsandis colored byJavanese culture. One that has beenstated earlieris thatasthe interest imposition motivethat is notjust basedonnumbers alone but rather bring kinship motive reflecting that accounting carries moral concern.

Nyedulur (kinship) is one of the social values that are still embedded in Javanese culture (Endraswara, 2002). At Pasar Besar Malang, nyedulur (kinship) attitude has been very rooted in both the soul of loansharks and the traditional market merchants who becomesthe debtors or not. Kinship implies a will to establish a union. Therefore in this study, the purpose of loanshark in impositioning interest is not solely for personal gain but the creation of a mutually agreed interest is a will to establish a union that is based on a long-term relationship orientation. These long-term relationships formed within social interactions and connectionsbetween illegal financial services agents with the traditional market merchants in Pasar Besar Malang. Kinship in accounting practices is a reflexivity of impositioninterest consequentcharged to debtors. It implies that the accounting rules do not only affect how the figures recorded in the accounts but also to help someone'sperspective and way of thinking to others (Francis, 1990). It is 
based on the view that accounting is a practice that is based on moral concerns not economic interests only.

\section{TracingPasar Besar Malang Loansharks DailyBusinessPractices}

Loansharksdaily activitiesespeciallyinthe Pasar Besar Malangcannot be separatedfrom setor (deposit)and nagih (collect). Depositwhich is called with setor is payment activitiesperformed bydebtorsandcollect which is called with nagih isbillingactivitiesconducted byloansharks. When loansharkscollectthe amount debtto the debtor, that is whenthe traditional market merchantsas thedebtorhas an obligation topay theinstallmentbased on thecharged amount. Itimplicatesthe emergence oflossand profit, lossand profit are both an advantage. loss and profit is a situationencounteredin loansharks dailylife.

Bathi (profit) and tekor (loss)is an issue thatcannot beseparated inrunning a business, loansharks business is no exception. Tekor lan bathi (loss and profit) islikesides of a coin. Gains inaccountingcan be called profit. Profitis the excessbetweenrevenues and expenses. Simply, when the number ofincomeis higher thantheexpensethen abusiness iscalled hasprofit(bathi), andvice versa, ifthe incomeis less than theexpense then a businesscan be saidin loss(tekor).

\section{Setor lan nagih (deposit and collect) : Between Accounting in Mind and Ewuh Pakewuh Culture}

The activities of setor lan nagih(deposit and collect)are the daily activities carried out by of financial services agents. Setor (deposit) and nagih (collect) activity is one of the accounting practices conducted by loansharks, whichcreates rights and obligations and the transfer of cash. When loansharkscollect debts, then there is an obligation for the market merchantsas a debtor to deposit the installment and the cash deposited toloansharks becomesthe right then turn into asset ofloansharks. Uniquely in the activities of billing, though without viewing the note,loan sharks does not miss anydebtor. As if memorized outside the head,loansharks come to thedebtor one by one. Loansharks also memorize the amount that should be paid by debtors. This is anapplication form of accounting, which can be practiced in the memories or thoughts (Espa, 2011).

Financial management in memory is an accumulation of performed habits forming an experience. Habits in carrying out daily activities form a conscious and subconscious area of the actor. Accounting practices within an organization also have different patterns, depending on the accounting environment in which they are used. This is similar the statement of Tricker (1978: 8) which says that the accounting in the ideology of cultural and moral society influence the accounting practices in the community, because the accounting is not value-free, and it is understood that accounting is a derivative culture where it is located. In this study, the illegal financial 
services agent integrates two kinds of accounting practices which are accounting in records and accounting in mind (memory). The application of accounting in the memory is very helpful in supporting loansharks business. The loansharks memories help accelerate the deposit and billing activities. Accounting for time in memory efficiency for depositing money lenders in the transaction and billing (setorlan nagih). Loansharks runsthe deposits and billing activity automatically. When they walk into the kiosk of the debtor, heget the signal and prepare the installments to be deposited. In Javanese culture it is an attitude called ewuh-pakewuh. As Mr. Darmin said:

(In Javanese) "Wes kebiasaan, nagihe nggih mboten kalih ndelok catetan. Alhamdulillah, sak pasar iki mboten wonten sing kelewatan. Pun apal. Saben nekani bedake, sak durunge kulo ngomong, pun ngerti dewe tiyange”

'It's a custom, the billing doesn't need notes. Thank God, I never miss anyone in this whole market. I memorized it already. Everytime I come, before I even speak, they already know."

The analysis showed that the meaning in Javanese culture known as ewuh pakewuh become a liability for the Java community to interpret the rules of Javanese life. The attitude of feeling badto people who are known is actually can be said to be a common attitude in society, but it became a special feature if it happens in the society and already have been entrenched. Further according (Marbangun, 1995) relativesrelation as a close relationshipwill lead to the attitude of ewuh pakewuh among people. Ewuh pakewuh characterizes Javanese who become one of way of life for most Javanese.

Ewuh pakewuh in Sanskrit means feeling bad (Purwadi and Purnomo, 2008). The attitude of ewuh pakewuh in the relationship ofloansharksand the market merchants in Pasar Besar Malangas debtors is, the attitude of uneasy feeling towards loansharks, so they do not want the loan sharks to wait a long time in collecting, so before moneylenders askthecharged nominal then the debtor has already prepared suitable amount of money requested. Loansharks in Pasar Besar Malang are considered as being the respected person for their large capital owned and religious backgrounds so many debtors call Ms. Saritem with Ummi call Saritem (mother Saritem) or Kaji Saritem (Haj) it has ewuh pakewuh cultural reflexivity. Symbiosis or close relationship makes people have the attitude of ewuh-pakewuh with inequality feedback given. Interwoven interactions with their ewuhpakewuh attitudeembodies Javanese values rooted in the Pasar Besar Malang people. Therefore, the culture ewuh pakewuh will make the process of billing and deposit conducted by loansharks easier. 


\section{TekorlanBathi(Loss and Profit) : The Consideration of Cash Basis, Net Present Value, Time Value of Money, and Nrimo ing Pandum}

Theaccounting existencealso appear inloansharkspracticesin determining thetekor (loss) orbathi (profit). In accounting studies, profitcan be simply definedas the excessbetweenrevenues and expenses, whenthe valueofthe incomeis greaterthanthe value ofthe spending. Apart fromthe consideration ofloss orprofitby NPVand thetime value of money approach.As said byMr. Darmin:

(In Javanese) "Ketingal sak iling kulo akeh sing nyetor saben dinone nggih bathi. Ingkang kulo silihaken balike nggih luwih.Makane niku tambah suwe tiyange mbalikaken nggih tambah larang bungane. Entuke sakpiro dino iku nggih disukuri mawon"

"It is a profit if I see many people deposit as I recall. The amountI lent, the repayment amountshould be larger. Therefore, the longerthe loan, the higher the interest. I'm thankful of whatever I get."

In determining the profits, loansharksalsoconsider aspects ofnet present valueand time value of money. NPVis the excessof the moneyspentwiththe money receivedina given time periodby taking into accountthe time value ofmoney. Accordingto Mediawati(2011), the time valueof moneyis to recognize thatthe value of commoditiesorcurrentmoneyvalue ishigher than thevaluein the future.This conceptmakes it possible toensurethe uncertainty ofincomethroughcompensationof uncertainty (premium ofuncertainty)that legitimatesin the interest application.

Loansharks, in addition to having the purpose of providingmerchants to capital, they also sought that the NPV must be positive or at least equal to zero. If it is negative, then their business is at loss. Loansharks must have been thinking of payback within a certain period of time. The returning rate is based on the agreement of the debtor and loansharks as the creditor, so the profit amount, tekorlanbathiis strongly related to consideration of Net Present Value.

The consideration of tekorlanbathi aspect according toloansharks business version is based on NPV aspect limited to the excess between the money received in a given time period by concerning the time value of money. The consideration time value of money done byloansharks is charged interest that depends on the term of the loan. The longer the loan term, the greater the interest charged. It is intended to benefit (bathi) and avoid losses (tekor).

Moneylenders in Pasar Besar Malang are willing to be repaid regardless. Theynever target the profit amount. There is no urge to deposit the appropriate amount if the debtor is deemed unable to pay. This makesloansharks in Pasar Besar 
Malangdifferent from loansharks elsewhere. They believe that business is not only about money. Businesspersons that have a background in Javanese consider that customers or clients are also considered as a distinct advantage. Treasure is not a reflection of the size of the property owned by an individual. It is one of the characteristics of Javanese peoplein which they are individuals who accept fate in their life and still believe in God's grace. In other words, all the things that happened in their life is left to the attitude ofnrimo ing pandum. Departing from this, the value nrimo ing pandum affect the accounting practices of loansharks in determining loss and profit (tekor lan bathi).

In determining the profits, loansharksalsoconsider aspects ofnet present valueand time value of money. NPVis the excessof the moneyspentwiththe money receivedina given time periodby taking into accountthe time value ofmoney. Accordingto Mediawati(2011), the time valueof moneyis to recognize thatthe value of commoditiesorcurrentmoneyvalue ishigher than thevaluein the future.This conceptmakes it possible toensurethe uncertainty ofincomethroughcompensationof uncertainty (premium ofuncertainty)that legitimatesin the interest application.

Loansharks, in addition to having the purpose of providingmerchants to capital, they also sought that the NPV must be positive or at least equal to zero. If it is negative, then their business is at loss. Loansharks must have been thinking of payback within a certain period of time. The returning rate is based on the agreement of the debtor and loansharks as the creditor, so the profit amount, tekorlanbathiis strongly related to consideration of Net Present Value.

The consideration of tekorlanbathi aspect according toloansharks business version is based on NPV aspect limited to the excess between the money received in a given time period by concerning the time value of money. The consideration time value of money done byloansharks is charged interest that depends on the term of the loan. The longer the loan term, the greater the interest charged. It is intended to benefit (bathi) and avoid losses (tekor).

\section{ACCOUNTING PRACTICES AND ILLEGAL FINANCIAL SERVICES STUDY IN THE PERSPECTIVE OF RESEARCHERS}

Researchers found that the loan sharks are still the favourite among merchants ofPasar Besar Malang. In connection with the preferences of the market merchants in Pasar Besar Malang which are inclined to loan sharks as the source of capital because the complicated procedural problem in formal financial services is in accordance with the mentality of getting short cuts fromIndonesian citizens as stated by Koentjaraningrat. Most merchants do not want to borrow to formal financial services with predetermined standard procedures for being rambling and time consuming. They think why choose the difficult sources of capital if there is an easier path. 
Koentjaraningrat describes getting shortcut mentality. In his book, Koentjaraningrat(1985) explains that one of the vices of the Indonesian people are getting shortcut. Getting shortcut is a desire to reach the destination quickly without wanting to do effort along with the stages from start to finish. This attitude is eventually followed by ugly traits such as loss of discipline, neglecting obligations and compromising quality. In other words,people who have a tendency to get shortcut mentality like to do against regulations.

Loansharksbusinessinthe Pasar Besar Malangis abusiness practicethat has been operatingfor decades. Its existenceis stillhighly favored bythe merchantsuntil today. Many regard loan sharkbusinesswas limited tothe provision ofdebtbetween theloansharksas theowner of the fundsandthe marketmerchantas the debtor. Yet, afterresearchers observesfor some time, the result wasmore than that. If examineddeeply, accountingappears in illegal financial services businessandhelpsmaintain their practices.

Credit providinginthe Pasar Besar Malang byloansharkstotraditional market merchantswhoarecustomersmore"ethical", oras researchers calledfor more "humanizing". Therefore, it is notsurprising ifthe most used illegal financial servicesby lots ofmerchants in traditional marketsistheloansharks(Maryatmo andRahayu, 2009:6). It has beendescribed in previous chaptersregarding factors that affectthe existence ofloansharksinPasar Besar Malang. There are severalfactors thatthe researchers deemmorehumanecompared toother financial services. These factorsareflexibility, ease of access, fast process, installment discounts, nopenalties, andnowarranties. We will seewhich financialservicesoffer "bolder" package ofloans.Presumably, thiscan be used asconsideration for the actorsorpractitionersinformalfinancial servicestobe studied.

The application of accounting practices with hints of local Javanese culture value makes loansharks business in the Pasar Besar Malang survived. The factors, which tend to provide convenience for traditional merchants as debtor, also contribute in the development of this illegal financial services business. It has implications for the growing number of customers who are interested in becoming debtorstherefore the more the benefit is gained by loansharks. It seems this love-and-hatesymbiosis produces an interaction which is closely related to the needs of capital provided by loansharks to the debtors. Debtors find it helpful for their financial services providing them financial needs with flexibility. Beside the high interest imposition, the application turns to be more humane that loansharks business in the Pasar Besar Malangincreasingly show theirexistence. If it is considered deeply, those factors indeed are humane, but how about the profits gained if the activity is very favorable to debtor.

Operational activities of loansharks in the Pasar Besar Malang arenot as pictured byloansharks elsewhere which in fact harms and become parasites for the market merchanta as customers. Loansharksactivities here are surfaced to color the life of market merchants as in the symbiosis of love-and-hate. Feeling hate when debtors 
have to pay interest more than bank interest rates, but feeling loved for the given loans tend to be flexible, fast processing, non collateral, non penalties, and even there is a reward in the form of credit terms cut. It is a turning point that the activities of loansharks in running their activities cannot be separated from the growing value system existing in a society. The values are learnedfrom loansharks in the Pasar Besar Malangis the value of strong Javanese culture with the principles of humanity. The intention of moneylenders in helping customers are more than just doing business only. Clearly, the interest rate is high, but it was coveredbyfast processing, ease of payment without bonds and fines, which make market merchants are "addicted" to the capital offered. Compared to conventional and Islamic banks, this service is considered more flexible. Loans in loansharks do not need rambling conditions as the formal financial services do. Researchers pay the attention that the loansharks in Pasar Besar Malang ranks first based on the humanitarian aspects compared to other financial services.

The concept usedbyloansharksinPasar Besar Malangis similarto the conceptraised byGrameenBank. GrameenBankisacreditprovider institutionthat offers credit tothe poorwithfreebond inBangladesh(Yunus, 2013: 90). GrameenBankprovides non-collateral creditforproductive activities.ForProfessorYunus, the requirements ofthebonds for thepoor are useless.This is thebenefit ofGrameenBank, which is the absence ofcollateral or guaranteeconditions. Furthermore, according to Yunus(2008: 12) in any country,banking institutionsmay not beable toprovide loanswithoutadequate collateralfrom the customer. The similar issuehappensinIndonesia. Thus, inconnection withthe studyof traditionalmarket merchantsinPasar Besar Malangare more likely to chooseloans fromloansharksbecause it is collateral-free.

This styleof loansharkisto be appliedbyProf.YunusinGrameenBank. Yet,not merelylegalizingloansharksbecause there are somefundamental differencesbetween loansharksandGrameenBank. The most fundamentaldifferenceis theGrameenBankservesthreekinds ofloans, whichareproperty development(peoples residential), productivecreditswhich earnsincome, and creditforfarming. LoansharksinPasar BesarMalangdo notrequireloanpurpose for their debtors.

\section{CONCLUSION}

Accounting is present and practiced in the illegal financial services business in Pasar Besar Malang. The findings clarify that the accounting practices of loansharks conducted in Pasar Besar Malang are based on the values of Javanese culture. By carrying Javanese culture values, business transactions carried out on market segmentation targeted by loansharks in Pasar Besar Malangimplicate the existence of illegal financial services in this location. The application of accounting practices has hints of local Javanese culture value to make loansharks business in the Pasar Besar 
Malang survives. The factors which tend to provide convenience for traditional merchants as debtor also contributes in the development of this illegal financial services business. It implicates for the growing number of customers who are interested in becoming debtorstherefore the more the benefit is gained by loansharks. It seemsloveand-hate symbiosis produces an interaction which is closely related to the needs of capital provided by loansharks to the debtors. They find the financial services helpful as it processes financial needs flexibly. Beside the very high interest imposition, it turns out that the application is more humane that make loansharks business in the Pasar Besar Malang increasingly showtheir existence.

From the results of this study it is concluded that: 1) The value of the local Javanese influence the shape ofloansharks business practices. 2) Traditional market merchants choose illegal financial services as their capital preference. 3) Factors affecting the existence of the loan shark are its flexibility. loansharks have the attitudes of the central elements of Javanese culture, which are the attitude of the Rila (willingness) and Nrima (receiving). 4) Loansharks are sincere in dealing with uncollectible credit caused by irresponsible debtor. 5) The consideration of loansharks capital decisions reflects aspects of going concern and skepticism. In Javanese culture, those aspects are very closely related to the attitude of being sharp (titis). 6) Loansharks produce accounting records in the form of "notes" and "buku besar" as a control and reflects simplicity. 7) Impositioned interest charged by loansharksreflect an attitude of nyedulur (kinship) that is based on a long-term relationship orientation inspiring accounting side to moral concern. 8) The process of setor lan nagih (depositing and collecting) shows that accounting activities evolve into accounting in memory and also brings ewuh-pakewuh attitude of loansharks and their debtors. 9) The existence of loanshark cash received each day is meant as a basis for determining profits (cash basis assumption), the simplicity of aspects of NPV and time value of money imposition 10)the loansharks never target for profit, reflecting the attitude of nrimo ing pandum. 


\section{REFERENCES}

Ahrens, T. dan M. Mollona.2007. Organisational Control as Cultural Practice - A Shop Foor Ethnography of Sheffield Steel Mill . Accounting Organization and Society. 32. 305-331.

Atkinson, P. 1988.Ethnomethodology: A Critical Review. Journal Annual Reviews Sociology, Vol.14, 441-465

Basrowi dan Sudikin. 2000. Metode Penelitian Kualitatif Perspektif Mikro. Cetakan Pertama. Penerbit Insan Cendikia.

Belkaoui, A.R, dan Picur, R.D. 1991. Cultural Determinism and Perception of Accounting Concepts. The International Journal of Accounting, (26), 118-130.

Boyle, R.D. dan H.B. Desai. 1991. Turnaround Strategies for Small Firms. Journal of Small Business Management.http://www.allbusiness.com (Diakses pada Agustus 2015).

Burrell, Gibson and Gareth Morgan. 1979. Sociological Paradigms and Organisational Analysis: Elements of the Sociology of Corporate Life. Heinemann: London.

Chapman C.S., D.J. Cooer, dan P.B. Miller. 2009. Linking Accounting, Organizations, and Institutions. Accounting, Organizations, \& Intitutions.C.S. Chapman., D.d. Cooper, dan P.B. Miller. Oxfor University Press:1-29.

Chariri, Anis. 2009. Landasan Filsafat dan Metode Penelitian Kualitatif, Paper disajikan pada Workshop Metodologi Penelitian Kuantitatif dan Kualitatif, Laboratorium Pengembangan Akuntansi (LPA), Fakultas Ekonomi Universitas Diponegoro Semarang, 31 Juli - 1 Agustus 2009.

Chua, Wai Fong. 1986. Radical Developments In Accounting Thought. The Accounting Review LXI (4): 601-32.

Creswell, John W., 1998. Qualitative Inquiry and Research Design.Choosing Among Five Traditions. Sage Publications Inc.

Creswell , J.W. 2009. Research Design Pendekatan Kualitatif, Kuantitatif, dan Mixed.Pustaka Pelajar: Yogyakarta.

Coulon, Alain. 2008. Etnometodologi. Jakarta: Penerbit Lengge bersama Kelompok Kajian Studi Kultural. Diterjemahkan dari L'ethnometodologie. Paris: Presses Universitaires de France.

Denzin, Norman K., And Yvonna S. Lincoln. 2009. Handbook Of Qualitative Research, Cetakan I. Penerbit Pustaka Pelajar. Yogyakarta. Penerjemah Dariyatno, Badrus Samsul Fata, Abi, John Rinaldi.

Ebrahim, A. 2003. Accountability in Practice: Mechanism for NGOs. World Development, 31(5), 813-829.

Endraswara, Suwardi. 2002. Etika Hidup Orang Jawa. Narasi: Yogyakarta

Espa, Vitriyan. 2011. Konstruksi Bentuk Akuntansi Keluarga (Pendekatan Hipnometodologi). Tesis. Malang: Program Pascasarjana Universitas Brawijaya.

Firmansyah dan Rizal E. Halim.2012. Strategi Revitalisasi Pasar Tradisional. Gramedia Pusaka Utama: Jakarta.

Francis, J. R. 1990. After Virtue?Accounting as a Moral and Discursive Practice.Accounting, Auditing, and Accountability Journal., 3 (3), 5-17. 
Garfinkel, H. 1967. Studies in Ethnomethodology. Prentice Hall: New Jersey.

Gray, S.J. 1998. Towards a theorh of Cultural Influence on the Development of Accounting Systems Internationally.Abacus, 24(1),1-15

Hofstede, G.H. 1987. The Cultural Context of Accounting, In Cushing, B. (ed)., Accounting and Culture, American Accounting Association, 1-11

Kartono, Drajat Tri. 2004. Pasar Modal Tradisional (Analisis Sosiologi Ekonomi Terhadap Rentenir). Jurnal Sosiologi DILEMA. Vol 17 (1). 1-9

Kieso, Weygandt dan Warfield. 2003. Accounting Intermediate 13th edition. New York: John Wiley \& Sons inc.

Koentjaraningrat. 1985. Metode-Metode Penelitian Masyarakat. Jakarta: Gramedia.

Ludigdo, Unti. 2007. Paradoks Etika Akuntan. Pustaka Pelajar: Yogyakarta.

Mason, J. 1996. Qualitative Researching.Sage: London.

Marbangun, Hardjowirogo. 1995. Manusia Jawa. PT Toko Gunung Agung: Jakarta.

Maryatmo, R dan Rahayu, Nyoman Yuyun Sri.2009. Hambatan Penyerapan Kredit Usaha Kecil Studi Kasus Di Pasar Anyar I Singaraja Bali 1.JEJAK.Vol. 2, No. 1.Maret 2009. 1-7

Mbogo, M. 2011. Influence of Managerial Ccounting Skills on SME's on the Success and Growth of Small and Medium Enterprises in Kenya. Journal of Language, Technology and Enterpreunership in Africa.Vol 3(1). 34-47

Mediawati, Elis (2011). Pembelajaran Akuntansi Keuangan Melalui Media Komik Untuk Meningkatkan Prestasi Mahasiswa. Jurnal Penelitian Pendidikan Vol 12 No. 1 April 2011.

Megginson, W.L., M.J. Byrd, and L.C. Megginson. 2000. Small Business Management: An Entrepreneur's Guidebook. Third Ed. Irwin McGraw-Hill. Boston.

Melzer, Brian dan Aaron Schroeder. 2015. Loan Contracting in the Presence of Usury Limits: Evidence from Auto Lending. Elsevier. 1-18

Morgan, G. 1988. Accounting as Reality Construction: Towards a New Epistimology for Accounting Practice. Accounting, Organizations, and Society, 13 (5), 477-485.

Muhadjir, N. 2000. Metodologi Penelitian Kualitatif, Rake Sarasin: Yogyakarta.

Nafik, Muhammad. 2009. Benarkah Bunga Haram?.Amanah Pustaka: Surabaya.

Palmer, G.D.,dan K.N. Palmer. 1996. Accounting, Marketing, and Management Function That Contribute to The Success of The Independent, Small, Rural, Retailer. http://www.sbaer.uca.edu. Januari 2011.

Perera, M.H.B. 1989. Towards a Framework to Analyze The Impact of Culture on Accounting. The International Journal of Accounting, 24(1),42-56

Permana, E.A. 2010.Bank Thitil Sebagai Underground Economy, Latar Belakang Timbulnya dan Implikasi Sosial Ekonomi di Perkampungan (Studi Kasus di Kecamatan Sukun, Kotamadya Malang) Tesis, Jurusan Ilmu Ekonomi Pembangunan Fakultas Ekonomi Universitas Brawijaya.

Poloma, Margaret M. 1979. Contemporary Sociological Theory.Macmillan Publishing. Purwadi dan Eko Priyo Purnomo.2008. Kamus Sansekerta Indonesia. Ebook: Budaya Jawa. 
Saputra, A. Aji, Multifiah, dan Asfi Manzilati. 2012. Praktik Bank Thithil dan Implikasinya Menurut Pandangan Masyarakat Muslim Wilayah Perkampungan Bethek Kota Malang. Tesis. Program Pascasarjana Fakultas Ekonomi dan Bisnis Universitas Brawijaya Malang..

Siamat, Dahlan. 1995. Manajemen Lembaga Keuangan. CV.Intermedia: Jakarta.

Soudijn, Melvin dan Sheldon Zhang. 2012. Taking Loan Sharking Into Account: A Case Study Of Chinese vest-pocket lenders in Holland. Springer Science Business Media.Journal of Trend Organ Crime.10(4), 213-251.

Sukoharsono, E. G. 2009.Refleksi Ethnografi Kritis: Pilihan Lain Teknik Riset Akuntansi .Audit Jurnal Akuntansi dan Bisnis. Vol. 4 No. 1, Januari 2009 91109.

Sutoyo.1990. Peranan Kebudayaan Jawa dalam Pengembangan Kebudayaan Nasional Indonesia, Masalah Pengembangan Kebudayaan Nasional Indonesia.Satya Wacana: Semarang.

Suwarjono. 2005. Teori Akuntansi Perekayasaan Pelaporan Keuangan. BPFE: Yogyakarta.

Triyuwono, Iwan. 2000. Organisasi dan Akuntansi Syariah. LKiS: Yogyakarta.

Yunus, Muhammad. 2008. Menciptakan Dunia Tanpa Kemiskinan. PT. Gramedia Pustaka Utama: Jakarta.

Yunus, Muhammad. 2013. Bank Kaum Miskin (Terjemahan). Marjin Kiri: Tangerang. Zulganef.2008. Metode Penelitian Sosial dan Bisnis. Graha Ilmu: Yogyakarta. 